\title{
Cien años de soledad: \\ a Macondo-América de Gabriel García Márquez como representação do continente latino-americano
}

Felipe de Paula Góis Vieira ${ }^{1}$

\section{Resumo:}

O livro Cien años de soledad - escrito pelo autor colombiano Gabriel García Márquez - foi lançado como romance, pela primeira vez, em 1967. Desde então, inúmeras reedições somaram mais de 150 milhões de exemplares, vendidos em 36 idiomas diferentes. O sucesso imediato da obra transformou García Márquez em um dos intelectuais mais reconhecidos e requisitados do continente. Além disso, difundiu-se uma ideia amplamente aceita e promovida pelos literatos do período de que Macondo, a cidade fictícia do romance, seria reflexo direto - ou, até mesmo, o perfeito retrato - da América Latina. $\mathrm{O}$ artigo tem por objetivo analisar as representações sobre o continente latino-americano dentro da obra. A intenção é compreender que tipo de América o escritor colombiano constrói e que tipo ele descarta, ao fundar esse microcosmo urbano.

Palavras-chave: Literatura hispano-americana, Cien años de soledad e representação.

\begin{abstract}
:
The book Cien años de soledad - written by the Colombian author Gabriel García Márquez - was released as a novel in 1967. Since then, more than 150 million copies have been sold in 36 different languages. The immediate success of García Márquez's work have made him one of the most recognized and sought intellectual on the continent. Moreover, a widely idea has been disseminated and well accepted and promoted by the literati of the period, that Macondo, the fictional city of the romance, would be a direct reflection - or even the perfect picture - of Latin America. The article aims to analyze the representations of the Latin American continent in this novel. The intention is to analyze which America is built and dropped by the Colombian writer when he has founded his urban microcosm.
\end{abstract}

Keywords: Spanish American literature, Cien años de soledad and representation.

\footnotetext{
${ }^{1}$ Mestre e doutorando em História Cultural pela Universidade Estadual de Campinas (UNICAMP) IFCH Departamento de História. Email: felipepgv@yahoo.com.br
}

Revista Eletrônica da ANPHLAC, n.12, p. 254-279, jan./jun. 2012. http://revista.anphlac.org.br/index.php/revista 
No dia 25 de junho de 2006, a cidade de Aracataca, terra natal do escritor colombiano Gabriel García Márquez, passou por uma situação, no mínimo, interessante. O pequeno povoado, situado na península de La Guajira, na costa caribenha da Colômbia, através de um plebiscito organizado por Pedro Sánchez Rueda - então prefeito da cidade -, quase teve seu nome trocado para Aracataca-Macondo, em referência à cidade de Cien años de soledad (1967), obra mais famosa do principal talento cataquero.

A medida tinha como intenção aproveitar a fama do nome Macondo, para ampliar o turismo e promover o desenvolvimento local. A proposta contou também com o apoio do diretor da casa-museu de García Márquez em Aracataca, Rafael Jiménez. Segundo o diretor, a mudança do nome "podría multiplicar los 3.000 peregrinos que el año pasado llegaron por su cuenta a visitar la casa donde nació el Nobel de Literatura 1982 y vivió hasta cumplidos 10 años [...]" (JIMÉNEZ, 2006).

$\mathrm{Na}$ véspera da votação, ao perceber que sua ideia não estava agradando, Pedro Sánchez Rueda subiu no teto de um Dodge Dart antigo repleto de alto-falantes e fez ele mesmo propaganda de sua "causa". Não adiantou, a proposta perdeu por abstenção. O referendo atingiu apenas 3.600 votos dos 7.400 necessários para aprovação do novo nome. No entanto, apesar da empreitada fracassada, uma faixa dizendo "Bienvenido a Aracataca-Macondo, tierra del realismo mágico" ainda tremula na estrada à vista dos visitantes que vão chegando à cidade.

Em entrevista ao jornal Inay, Rueda explica a origem de sua ideia:

\begin{abstract}
Esta idea precisamente nació por mi ida a Europa. Allá tuve la oportunidad de viajar a cinco países y, en ellos, me preguntaron por Aracataca y Macondo. Que si eran lo mismo. Entonces, para que la gente no se confunda pensé agregarle Macondo a Aracataca porque aquí está la materia prima de la obra de Gabo. ${ }^{2}$
\end{abstract}

Essa entrevista expõe uma questão central para a realização deste artigo: a forma como Cien años de soledad se consolidou, ao longo dos anos, como o romance "latinoamericano" por excelência e, por consequência, Macondo como uma representação possível - e, por vezes, considerada fidedigna - de Aracataca, da Colômbia e do próprio

\footnotetext{
${ }^{2}$ Entrevista dada por Elena Castellar González ao jornal Inay, n.3, abril de 2006. Disponível em: $<$ http://www.usergioarboleda.edu.co/altus/inay.pdf $>$. Acesso em 01/08/2011.
} 
continente $^{3}$. Essa visão parece pairar no senso comum europeu/norte-americano/latinoamericano e, quando conveniente, engendra iniciativas como a do prefeito de Aracataca. Para muitos jornalistas e parte da crítica especializada, esse seria um episódio possível de ser narrado nas inúmeras páginas de García Márquez ou da estética narrativa do realismo mágico. Para o olhar do historiador, mais do que anedota cotidiana, essa intenção nos permite entrever certo uso político da literatura consagrada no continente.

Essa confusão generalizada entre a Macondo literária e a terra natal de García Márquez traz à tona o chamado "efeito de real" ${ }^{4}$ da obra literária e seu possível poder de, como texto, criar realidades duradouras e férteis. Se Aracataca serviu possivelmente de inspiração para García Márquez na criação de Macondo, agora é Macondo que faz com que os leitores de Cien años de soledad lancem um novo olhar sobre a cidade. Em outras palavras, se subjacente à retórica do prefeito há a crença de que a literatura é genericamente considerada uma espécie de documento de ilustração da história, não se pode negar, por outra perspectiva, que a literatura de García Márquez estimulou a criação de museus e até mesmo passeios turísticos como a "Ruta Macondo" 5.

Certamente, o sucesso de Cien años de soledad e Macondo - assim como seu potencial poder de representar a América Latina - foi construído ao longo dos anos. A cidade está presente na obra de García Márquez, desde sua estreia literária em La hojarasca $^{6}$ (1955), aparecendo também em livros como El coronel no tiene quien le escriba (1961), La mala hora (1961) e Los funerales de la Mamá Grande (1962). De

\footnotetext{
${ }^{3}$ Para o crítico literário José Miguel Oviedo, por exemplo, "Macondo ha sido inventado a partir de datos muy concretos de una zona real de Colombia (el mundo de la costa atlántica, con sus pueblitos y sonámbulos), donde la miseria es natural, el calor implacable, la vida calamitosa y la política bárbara". In: OVIEDO, José Miguel. "Cien años de soledad de García Márquez” In: GOIC, Cedomil. Historia y crítica de la literatura hispanoamericana. Barcelona: Crítica, p. 459-463. p.459

${ }^{4} \mathrm{O}$ texto literário precisa ser convincente e articulado, estabelecendo uma coerência e dando impressão de verdade. Escritores de ficção também contextualizam seus personagens, ambientes e acontecimentos para que recebam aval do público leitor. Longe de admitir a ideia de que a literatura funciona como espelho da sociedade, estaríamos, segundo a historiadora Sandra Jatahy Pesavento, diante do "efeito de real" fornecido pelo texto literário. PESAVENTO, Sandra Jatahy. História \& literatura: uma velha-nova história. Nuevo Mundo Mundos Nuevos, Debates, Paris, s/n, p.7, 28 de janeiro de 2006.

${ }^{5}$ Em 2010, foi inaugurado um passeio turístico que liga a cidade de Santa Marta ao norte da Colômbia, para levar turistas até a cidade de Aracataca. A rota, baseada no romance Cien años de soledad, é recheada de referências ao universo literário de García Márquez e se faz através de um "trencito amarillo", trem que ligava a cidade literária de Macondo ao resto do mundo. A inauguração da rota contou, inclusive, com a participação do escritor colombiano.

${ }^{6}$ Nessa obra, além de Macondo, há a aparição da Companhia Bananeira, das guerras civis e de outros temas e personagens que mais tarde povoariam o universo literário de Cien años de soledad. Para uma visão panorâmica do tema, sugerimos como leitura: LUCENA, Karina de Castilhos. Os caminhos de Aracataca a Macondo. In: Antares, Letras e Humanidades, Caxias do Sul, n. 1, p. 183-200, jan-jun 2009.
} 
uma forma geral, nos anos subsequentes à publicação do romance, autores consagrados do boom e críticos literários não hesitaram em transformar a Macondo de García Márquez no retrato perfeito e verdadeiro da América Latina. Dentro dessa perspectiva, por exemplo, Enrique Anderson Imbert, escritor e renomado ensaísta argentino, classifica: "Macondo [...] es Colombia y también toda nuestra América" (1995, p.353). Em linhas gerais, essa também é a interpretação do ensaísta chileno Luis Harss: "Macondo, más un ambiente que un lugar, está en todas partes y en ninguna. Quienes van allá emprenden un viaje interior que hace escala en el rostro oculto de un continente" (1969, p.384). Podemos citar ainda o escritor e ensaísta uruguaio, Mario Benedetti:

[...] ese Macondo de colombiana postura es, en última instancia, una suerte de gran (y modesta) plataforma latinoamericana donde García Márquez instala, gracias a una alegre y semoviente metáfora, un estado de ánimo poco menos que continental [...]. Ese propósito de fabricarse una geografía a escala personal, podría llegar a interpretarse como un gesto secreto, casi clandestino, destinado a latinoamericanizar un dato geográfico local, restringido. (BENEDETTI, 2000, p.360)

Para o escritor peruano Mario Vargas Llosa:

A grandeza maior de seu livro [Cien años de soledad] reside, justamente, no fato de que tudo nele - as ações e os cenários, mas também os símbolos, as visões, as feitiçarias, os presságios e os mitos - está profundamente ancorado na realidade da América Latina, dela se nutre e, transfigurando-a, acaba refletindo-a de maneira certeira e implacável. (LLOSA, 2006, p.157)

As palavras de Vargas Llosa apontam também para outro dado: a ideia de que as ações fantásticas ou "maravilhosas" - feitiçarias, presságios, mitos - do romance encontram paralelo perfeito dentro da realidade do continente. Em obra recentemente lançada, Dicionário Amoroso da América Latina, o escritor peruano faz novamente uso dessa estratégia discursiva. No vocábulo referente a Aracataca, Vargas Llosa descreve Macondo, insistindo na confusão ou relação entre a obra literária e a realidade:

No nosso universo, não existe o impossível, tudo pode acontecer. Sair o sol à noite, a lua durante o dia, se interromper a lei da gravidade para que as pessoas possam dar um passeio nas nuvens, se disso tiverem vontade. Aqui, os gordos são magros; os magros, gordos; as feias, bonitas; as crianças, velhos; os cães miam, e os gatos ladram; e os vivos, os mortos e os fantasmas são indiferenciáveis, igual aos ratos e às borboletas, duas aves de curral. Para conhecer a verdadeira Aracataca, é preciso fechar os olhos e deixar que a fantasia se ponha a cavalgar. (LLOSA, 2006, p.28)

Revista Eletrônica da ANPHLAC, n.12, p. 254-279, jan./jun. 2012. http://revista.anphlac.org.br/index.php/revista 
Essa noção, amplamente difundida, de que ontologicamente a realidade latinoamericana era diversa, capaz de concatenar aspectos considerados mágicos ao chamado mundo real, não é nova. Como se sabe, o escritor cubano Alejo Carpentier a havia formulado antes, em um texto publicado originalmente no El Nacional da Venezuela, em 1948, sob o título de "Lo real maravilloso en América". Em 1949, esse texto daria origem ao prólogo de El reino de este mundo - segundo romance de Carpentier.

Esse que parece ter sido o grande argumento da nova narrativa hispanoamericana criou um campo fértil para a propagação da ideia de que a literatura do continente seria reflexo direto de sua realidade. García Márquez, Vargas Llosa, Carpentier e tantos outros nomes foram responsáveis por criar um conceito cultural sobre a América, um ideário sobre a significação do continente no cenário mundial. A repetição de certos argumentos em suas obras evidencia que entre eles se travou um intenso e profícuo diálogo, que ajudou a consolidar uma imagem pasteurizada sobre a literatura do período. Ao atribuírem-se o papel de desvelar a realidade latino-americana, acabaram criando formas específicas de representação da América Latina, fornecendo respostas convincentes sobre o que seria uma suposta identidade latino-americana. Em especial, na década de 1960 e início dos anos 1970, anos do boom dessa narrativa, foram produzidos vários livros de grande repercussão nos círculos literários internacionais ${ }^{7}$.

Esses livros, avidamente consumidos, habituaram leitores de todo mundo a perceber a América como o espaço do maravilhoso, do exótico etc. E, de uma forma ou de outra, Cien años de soledad representou a projeção internacional definitiva dessa literatura. Para José Donoso (1983, p.36), intelectual chileno, o momento auge de expansão comercial do boom teria sido alcançado com a publicação do romance. Livro que, segundo ele, rendeu ao escritor colombiano êxito de crítica, público e venda em quase todos os países onde foi publicado ${ }^{8}$.

\footnotetext{
${ }^{7}$ Se por um lado, escritores como Julio Cortázar, Gabriel García Márquez, Carlos Fuentes, Mario Vargas Llosa escreveram suas obras fundamentais, por outro, escritores já consagrados como Juan Rulfo, Adolfo Bioy Casares, Ernesto Sábato e o próprio Carpentier ganharam projeção internacional nesse período.

${ }^{8}$ Dentro dessa perspectiva, Ángel Rama destaca: "Fue ese libro el que dio contextura al aún fluyente e indeciso boom, le otorgó forma y en cierto modo lo congeló como para comenzar a extinguirse". Ainda para o crítico literário uruguaio, o ponto alto da produção editorial do período foi a publicação do romance. De 1968, um ano após a primeira tiragem de 25.000 exemplares, ao final dos anos 70 , Cien años de soledad vendeu em média 100.000 exemplares, o que significou uma revolução nas vendas de
} 
García Márquez chegou a afirmar em discurso, por ocasião do IV Congreso Internacional de la Lengua Española, enquanto recebia uma homenagem por ter atingido o número de 150 milhões de exemplares vendidos, que: "los lectores de Cien Años de Soledad son hoy una comunidad que si viviera en un mismo pedazo de tierra, sería uno de los veinte países más poblados del mundo" (MÁRQUEZ, 2007).

Essa afirmação prova que Macondo se tornou um território incorporado definitivamente ao mapa da literatura ocidental, ou pelo menos, latino-americana. Mais do que isso, virou uma espécie de sinônimo do realismo mágico, representando, mesmo que idilicamente, o desejo de unidade da América Latina.

Obviamente, essa incorporação trouxe à tona alguns problemas. Para Emil Volek, doutor em Letras Hispânicas e professor do Departamento de Línguas e Literatura da State University, Tempe, Estados Unidos, a realidade de Macondo fora tão graciosa e hilariante, que "fascinó al público extranjero, que tomó todo esto por la realidad latinoamericana, y pidió más" (VOLEK, 2007, p. 307). A força arquetípica de Macondo tem sido tal, que o sociólogo chileno José Joaquín Bruner (BRUNER, 1989) tem escrito e falado contra o "macondismo": essa generalizada distorção que sobre a América Latina têm construído certos intelectuais europeus e norte-americanos, e tem por pressuposto a metáfora - também alimentada por García Márquez e grande parte dos intelectuais da década de 1960 - de que o continente teria fornecido o substrato necessário para a criação do microcosmo ficcional de Macondo. Em outras palavras, a ideia de que a cidade ficcional de García Márquez representaria indiscutivelmente toda a América Latina.

Assim, ao consolidar-se como cânone literário, Cien años de soledad - como tenho argumentado - criou uma forma específica de retratar a América que, em certo

romance no continente. RAMA, Ángel. "El boom en perspectiva”. In: Signos Literarios, México, n. 01, pp. 161-208, janeiro-junho de 2005, p.190.

9 O termo indica a forma como a obra de García Márquez, em especial Cien años de soledad, tem sido recebida e usada em determinados círculos intelectuais. Para Brunner, macondismo seria certa atitude de interpretar a América Latina através "de las bellas letras" ou, mais exatamente, como produto exato dos relatos que se contam a partir de sua literatura. Segundo ele, a crença de que esses relatos, em especial aqueles produzidos pelo boom da década de 1960 - sobretudo quando são aclamados pela crítica estrangeira -, são constitutivos da realidade latino-americana ou a expressam literalmente é um efeito real dessa atitude. Para Emil Volek, dentro dessa mesma perspectiva, "Hoy en día, el macondismo no afecta sólo a la intelectualidad latinoamericana sino que se ha expandido por toda la academia del Primer Mundo, cuyo imaginario ha quedado anclado mayormente en la década 'heroica' de los años sesenta". Para melhor compreensão do tema: VOLEK, Emil. José Martí, Nuestra (Macondo) América. In: Revista Universum, Talca, n. 22, vol.1, p. 300-317, 2007. 
sentido, tonou-se bastante profícua e consolidada no senso comum, dentro e fora do continente.

\section{A elaboração do romance dentro da mitologia sobre Gabriel García Márquez}

Segundo Eric Nepomuceno (2009, p.15), a verdade é que ninguém - nem o próprio Gabriel García Márquez - parece capaz de lembrar o dia, a semana ou o mês em que foi escrita a primeira frase de Cien años de soledad. Tudo o que se sabe é que foi numa terça-feira de 1965. E que o mais provável é que tenha acontecido entre o final de junho e o começo de agosto. É certo, porém, que aconteceu na Cidade do México, na rua Loma, número 19, em San Angel Inn, um bairro classe média da capital mexicana.

Quando escreveu a famosa primeira frase, o autor colombiano estava com 37 anos de idade e, como conta Nepomuceno (2009, p.15), havia chegado à Cidade do México quatro anos antes, depois de uma agitada temporada em Nova York, onde havia sido correspondente da agência cubana de notícias Prensa Latina. Levava pouco mais de duzentos dólares no bolso, nenhum vislumbre de emprego ou trabalho e a determinação de se transformar em roteirista de cinema e se estabelecer de vez como escritor.

Entre o dia da sua chegada ao México e o amanhecer da véspera em que se sentou diante da máquina de escrever e começou a primeira frase do livro que mudaria a sua vida, a trajetória de García Márquez navegou, segundo Nepomuceno, "ao sabor de ventos variados" (2009, p.15). Em 1961, o escritor colombiano era, na verdade, um quase desconhecido. Tinha escrito quatro livros e apenas um, La hojarasca, fora publicado na Colômbia, sem maiores glórias que algumas resenhas elogiosas. Trechos desses livros e alguns contos haviam sido editados em publicações de prestígio no México, seu nome circulava com relativo trânsito entre artistas e intelectuais, mas ele estava longe de ser um nome conhecido fora desse ambiente restrito.

Sua vida tomou um rumo diferente apenas em 1965. Após quatro anos vivendo no México, García Márquez se tornou um roteirista muito bem cotado e um escritor cada vez mais reconhecido e requisitado por editores de vários países latino-americanos. Com as profissões de publicitário e roteirista, ganhava um bom dinheiro, morava em 
uma casa confortável, pertencia a círculos importantes da vida cultural mexicana e era dono de uma boa coleção de amigos influentes ${ }^{10}$.

Mas, apesar do rumo promissor, García Márquez, segundo conta Nepomuceno (2009, p.21), não estava feliz. Nos últimos cinco anos, não havia escrito um conto, não havia começado nenhum romance, nem voltara, para valer, a algum projeto abandonado. Queixava-se, aos amigos mais íntimos, de aridez total.

E, nesse clima de incerteza e desgaste, o escritor colombiano decidiu levar a família para umas curtas férias em Acapulco. Segundo Gerald Martin (2008, p.365366), foi na estrada, pilotando um Opel branco, que brotou a primeira sentença de todo o romance.

\begin{abstract}
Naquele dia, ainda não havia dirigido por um longo percurso, quando, "de lugar nenhum", a primeira sentença de um romance lhe flutuou na mente. Por trás dela, invisível, mas palpável, estava o romance inteiro, como se tivesse sido ditado - baixado - do além. Era tão poderoso e irresistível quanto um feitiço, um encantamento mágico. A fórmula secreta da sentença estava no ponto de vista e, acima de tudo, no tom: "Muitos anos depois, diante do pelotão de fuzilamento [...]". Como se estivesse em transe, García Márquez parou, deu meia-volta no Opel e voltou para a Cidade do México. E então... (MARTIN, 2008, p.366) ${ }^{11}$
\end{abstract}

Anos mais tarde, García Márquez diria que, após ter chegado a sua casa, sentarase à máquina de escrever no dia seguinte, como fazia todos os dias, exceto que "desta vez não levantaria nos próximos 18 meses" (Apud MARTIN, 2008, p. 366). Nas inúmeras páginas que se seguiram, o escritor colombiano narrou a saga de sete gerações da família Buendía, vivendo num intervalo de cem anos de história.

\footnotetext{
${ }^{10}$ Como lembra Adriane Vidal Costa, é pertinente destacar que a consagração de Cien años de soledad se deve, em grande medida, ao papel da rede intelectual latino-americana de esquerda, que vinha se formando desde 1960. Costa afirma que, antes mesmo de ser publicado pela editora argentina Sudamericana, em 1967, Cien años de soledad já era um romance esperado, promovido e aguardado pela crítica especializada e pela rede intelectual do que mais tarde seria conhecido pelo nome de boom. Um dos seus grandes promotores foi sem dúvida Carlos Fuentes, escritor mexicano responsável pela publicação parcial do romance em inúmeras revistas e suplementos literários do México; além de Vargas Llosa, principal responsável pela promoção do romance como a novela definitiva do continente. Em outras palavras, "o êxito de vendas desse livro se deve, em grande medida, à existência dessa rede de escritores que queriam tornar a literatura latino-americana (re)conhecida dentro e fora do subcontinente". In: COSTA, Adriane Vidal. Intelectuais, política e literatura na América Latina: o debate sobre revolução e socialismo em Cortázar, García Márquez e Vargas Llosa (1958-2005). Belo Horizonte, 2009. Tese (Doutorado em História) - FAFICH/UFMG. p. 149-154.

11 Segundo Martin, existem várias versões para essa história. Uma segunda possibilidade, essa compartilhada por Nepomuceno, relata a possibilidade de que García Márquez não teria retornado sumariamente à Cidade do México após a suposta revelação da frase. Dentro dessa perspectiva, o escritor colombiano teria passado o fim de semana em Acapulco, dando voltas, ansioso, totalmente embebido pelo livro, e só na manhã de uma incerta terça-feira, já de regresso à capital mexicana, teria se sentado para começar a escrever o livro.
} 
A narrativa do romance começa e termina num estilo bíblico e abrange, segundo Martin (2008, p.372-373), alguns dos mitos universais da antropologia, algumas das fábulas e lendas características da cultura ocidental, bem como a peculiar crença negativa na própria experiência específica de grandiosa aspiração e de fracasso humilhante da América Latina. Juntava-se a tudo isso, histórias específicas de sua família à história do continente, unindo ingredientes literários latino-americanos Borges, Asturias, Carpentier e Rulfo - com a Bíblia, com Rabelais, com as crônicas da conquista espanhola e com as novelas europeias de cavalaria. O livro se passava em Macondo, mas Macondo era, agora, uma metáfora para a América Latina inteira.

O sucesso da obra foi imediato e fulminante. A tiragem inicial de dez mil exemplares esgotou-se em quinze dias. Veio, como afirma Nepomuceno (2009, p.24), uma segunda, de outros dez mil, que teve o mesmo destino. Em três anos, foram 600 mil exemplares em castelhano, e em oito, as vendas chegaram a dois milhões. Em 1982, quando García Márquez foi contemplado com o prêmio Nobel de literatura, só em castelhano, 25 milhões de exemplares de Cien anos de soledad tinham sido vendidos. Quando García Márquez celebrou 80 anos de vida, em março de 2007, as vendas chegavam a 150 milhões de exemplares em 36 idiomas. Diante do sucesso estrondoso da obra, o escritor colombiano tornou-se uma das vozes mais requisitadas do continente.

Para Karla Pereira Cunha (2007, p.64), na interpretação do romance, podemos observar basicamente dois caminhos divergentes. Há críticos literários e historiadores, que veem a obra como a representação do local: do Caribe, da Colômbia e por extensão da América Latina; ou seja, o romance é visto como espaço de representação da história, uma espécie de metáfora da situação latino-americana entrelaçada com a história da Colômbia. Outros buscam pensar a obra dentro do cruzamento entre história e mito. Nessa interpretação, o romance é visto como criação e síntese do mundo, sendo estruturado de forma mítica, uma metáfora da condição humana revelada através dos membros da família Buendía.

Para Cristo Figueroa (1998, p.113), não é estranho que a extensa bibliografia crítica sobre o romance manifeste uma contraposição de leituras, entre aqueles que a interpretam fundamentalmente como uma grande metáfora da condição humana - Julio Ortega, Carmen Arnau ou José Miguel Oviedo - e aqueles que a veem, sobretudo, como uma chave de acesso ao contexto histórico do continente - Ángel Rama, Emmanuel 
Carballo ou Isaías Lernes. Enquanto os primeiros apoiam seus argumentos na circularidade do tempo, no inexorável determinismo que rege a vida dos Buendía, na solidão que pesa sobre seus personagens, na impotência ante as forças indomáveis da natureza e dos instintos dos homens, para os últimos, o que importa na obra é a denúncia dos problemas sociopolíticos locais, a matança dos trabalhadores, a violência imposta pelo poder, o roubo de terras e a opressão ostensiva sobre os excluídos e fracos.

Outro setor crítico prefere, ainda, referir-se a uma dupla significação de Macondo (Palencia Roth ou Lucila Inés Mena), segundo a qual o dito espaço literário, ao mesmo tempo em que se conecta com realidades históricas determinadas, possui suficiente autonomia para plasmar simbolismos de ressonância universal ${ }^{12}$.

A intenção deste artigo é analisar algumas das representações do continente latino-americano contidas no livro, embora não nos interesse entender a qual processo histórico específico o texto de García Márquez faz referência. Intentamos, sobretudo, analisar qual América constrói e descarta o escritor colombiano, ao fundar o seu microcosmo urbano.

\section{Macondo como utopia}

Como já comentado, Cien años de soledad narra a história da fictícia cidade de Macondo e a ascensão e queda de seus fundadores, a família Buendía. Os seis personagens centrais, que dão início ao romance e dominam a primeira parte, são: José Arcadio Buendía, o entusiasmado fundador da vila de Macondo; a esposa dele, Úrsula Iguarán, espinha dorsal não só da família, mas também do romance inteiro; os filhos, José Arcadio e Aureliano - o último, coronel Aureliano Buendía, considerado em geral o principal personagem do livro; a filha, Amaranta, atormentada quando criança e

\footnotetext{
${ }^{12}$ A respeito das linhas interpretativas que assimilam Cien años de soledad como uma grande metáfora da condição humana, ver: ORTEGA, Julio. La contemplación y la fiesta. Ensayos sobre la nueva novela latinoamericana. Lima: Editorial Universitaria, 1968. p. 45-58.; ARNAU, Carmen. El mundo mítico de Gabriel García Márquez. Barcelona: Ediciones Penísula, 1975.; OVIEDO, José Miguel. Op. Cit. Com relação a uma leitura que privilegia a perspectiva da história latino-americana, ver: RAMA, Angel. Transculturación narrativa en América Latina. Bogotá: Siglo XXI, 1988; CARBALLO, Emmanuel. Un gran novelista latinoamericano. In: Gárcia Márquez, colección el escritor y la crítica. Madrid: Taurus, 1982. Pp. 22-37; LERNES, Isaías. A propósito de Cien años de soledad. In: Cuadernos americanos, México, n.1, p.186-200, jan-fev de 1969. A dupla significação de Macondo é objeto de estudo dos livros: MENA, Lucila Inés. La función de la historia en Cien años de soledad. Barcelona: Plaza y Janés, 1979 e ROTH, Michael Palenecia. Gabriel García Márquez: la línea, el círculo y las metamorfosis del mito. Madrid: Gredos, 1983.
} 
amargurada como mulher; e o cigano Melquíades, que traz as notícias do mundo exterior e, por fim, estabelece-se em Macondo.

A história da Colômbia é dramatizada por intermédio de dois eventos principais: a Guerra dos Mil Dias e o massacre dos trabalhadores bananeiros em Ciénaga, em 1928. Essas eram, segundo Martin (2008, p.368), as principais referências históricas que formavam o contexto da própria infância de García Márquez.

Como lembra Karina de Castilhos Lucena (2008, p.25), no interior da obra, o povoado foi fundado pelo patriarca José Arcadio Buendía, juntamente com sua esposa e mais vinte e uma famílias amigas, que aceitaram adentrar a "sierra impenetrable" (MÁRQUEZ, 2011, p.20), pois não havia nada que os prendesse a Riohacha, o lugar onde viviam.

O único que tinha motivo concreto para afastar-se da aldeia era José Arcadio, que não podia suportar o peso de uma morte. O patriarca dos Buendía casara-se com sua prima Úrsula, contra a vontade da família de ambos. A todo custo, a mãe de Úrsula procurou dissuadi-la do casamento, alegando que os netos teriam um futuro estarrecedor, devido a um comprovado precedente nas duas famílias: de uma relação incestuosa nasceriam crianças com rabos de porco ou iguanas. Para evitar o destino, Úrsula passou a usar um cinto de castidade, que vestia à noite, para conter as investidas do marido.

Certo dia, José Arcádio, devido às insinuações públicas e afrontosas de Prudencio Aguilar sobre sua virilidade (não tinha filhos depois de um ano de casado), cometeu um assassinato, matando o difamador com um corte certeiro no pescoço. A partir de então, o fantasma do morto passou a perturbar os Buendía de tal modo, que José Arcadio resolveu fugir com sua esposa da aldeia. Ele chamou um grupo de amigos que aceitaram participar da travessia da serra pantanosa rumo ao mar.

A viagem é descrita no romance como absurda, prolongando-se por vinte e seis meses, durante os quais, para evitar a fome, os viajantes tiveram de comer carne de mico e sopa de cobras. Após percorrer uma imensa área de matos, serras e pântanos, finalmente, os precursores da nova comunidade, cansados de tentar encontrar uma saída para o mar, acabaram por fundar o povoado de Macondo, em uma região escolhida mais ao acaso do que por planejamento. A única preocupação daquelas vinte e uma famílias era "viajar en sentido contrario al camino de Riohacha para no dejar ningún rastro ni 
encontrar gente conocida" (MÁRQUEZ, 2011, p.35). O que os aventureiros desejavam, desesperadamente, era uma nova vida, longe dos fantasmas do passado ${ }^{13}$ :

\begin{abstract}
Atravesaron la sierra buscando una salida al mar, y al cabo de veintiséis meses desistieron de la empresa y fundaram Macondo para no tener que emprender el camino de regreso. Era, pues, una ruta que no le interesaba, porque sólo podia conducirlo al pasado. (MÁRQUEZ, 2011, p.20)
\end{abstract}

Assim, Macondo foi fundada junto às margens de um "río de aguas diáfanas que se precipitaban por un hecho de piedras pulidas, blancas y enormes como huevos prehistóricos" (MÁRQUEZ, 2011, p.9). Nesse sentido, a fundação do povoado transforma-se em um exemplo de mito de origem, remontando ao gesto de criação do mundo. Para Figueroa (1998, p.14), trata-se da fundação do paraíso terrestre, em alusão direta ao texto bíblico ${ }^{14}$.

${ }^{13}$ Selma Calasans Rodrigues possui uma interpretação bastante interessante com relação à fundação de Macondo. Interpretando a construção do romance como uma grande metáfora da história hispanoamericana, a autora afirma que o gesto de fundação do pequeno povoado, assim como a necessidade de deixar o passado para trás, diz muito sobre a construção da identidade no continente. Apoiada em Leopoldo Zea - Dialéctica de la conciencia americana (1960) -, a autora afirma que o ibero-americano é o mais vocacionado dos americanos a uma eliminação do passado, vivendo um presente que aspira a ser distinto. Zea afirma que o ibero-americano vê em seu passado a impossibilidade de um futuro, de um "vir-a-ser". Trata-se de sentir o passado como um obstáculo a transpor: a violência da colonização, a depredação dos grandes impérios inca, maia e asteca, em especial, são os móveis desse sentimento, na origem. Enquanto o americano do norte, orgulhoso de seu passado de peregrino que buscou a liberdade em terras novas, fazia desse um instrumento do futuro, assimilando-o, o ibero, ao contrário, tinha que enfrentar esse passado, destruindo-o, por considerá-lo a causa da impossibilidade de construir o seu novo ser. Daí o filósofo mexicano acentuar o traço do ibero-americano do ser inacabado, que se caracteriza sobretudo por aquilo que quer chegar a ser, negando um passado para buscar algo distinto e vivendo sempre à espera desse algo. In: RODRIGUES, Selma Calasans. Macondoamérica: a paródia em Gabriel García Márquez. Rio de Janeiro: Leviatã Publicações, 1993. p.39

${ }^{14}$ Ainda segundo Figueroa, é possível observar uma conexão direta e indireta de Cien años de soledad com a Bíblia e a mitologia do Antigo Testamento. A narrativa bíblica proporciona elementos básicos para a estruturação do romance e engendra um marco sugestivo em que o leitor, formado na tradição judaicocristã, reconhece história a anjos e demônios, às profecias, ao dilúvio universal etc. Além disso, abundam fórmulas de linguagem que recriam a forma do texto bíblico: "A imagen y semejanza", "por los silgos de los siglos", "infundió un soplo de vida", "fue concebido y dado a luz" ou "o arrasar a Macondo de la faz de la tierra". Podemos afirmar que a Bíblia funciona como uma espécie de "intertexto" que organiza arquetipicamente o material narrativo: gênesis, êxodo, pecado original, castigos e profecias, apocalipse e juízo final. In: FIGUEROA, Cristo. Cien años de soledad: reescritura bíblica y posibilidades del texto sagrado. In: XX Congreso Nacional de Literatura, Linguística y Semiótica: Cien años de soledad, treinta años después. Santafé de Bogotá: 1998. p.114. No entanto, como afirma Selma Calasans Rodrigues, a escritura da obra obedece à lógica da paródia, negando qualquer suporte teológico e/ou teleológico que se lhe queira atribuir, e se constitui numa flagrante ruptura com o aspecto sacro do texto bíblico. Para a autora, o primeiro elemento paródico percebido no texto é a inversão da cronologia bíblica, alterando a ordem dos mitos acima referidos. Reconstituindo a fábula do romance, verificamos que a criação do "paraíso" (a fundação de Macondo e da ficção) é precedida pelo pecado da origem (a prática do incesto), pelo primeiro crime (o fratricídio simbólico) e pelo "êxodo". A narrativa se estrutura a partir daí, pelas "pragas" e só perto do final tem-se o "dilúvio", seguido do "apocalipse". Essa inversão, segundo a autora, já é um elemento forte para constatar que se trata de um texto dessacralizador. In. RODRIGUES, Selma Calasans. Op. Cit. p.74.

Revista Eletrônica da ANPHLAC, n.12, p. 254-279, jan./jun. 2012. http://revista.anphlac.org.br/index.php/revista 
E, como afirma Lucena (2008, p.28), uma vez estabelecido o lugar de fundação, era necessário organizar o povoado internamente. Quem comanda o processo é José Arcádio:

\begin{abstract}
José Arcadio Buendía, que era el hombre más emprendedor que se veria jamás en la aldea, había dispuesto de tal modo la posición de las casas, que desde todas podía llegarse al río y abastecerse de agua con igual esfuerzo, y trazó las calles con tan buen sentido que ninguna casa recibía más sol que otra a la hora del calor. (MÁRQUEZ, 2011, p.18-19)
\end{abstract}

Para Nadia Terezinha Arzivenko Forgiarini (2009, p.54), essa descrição conserva algo de um mundo ideal. É importante que se entenda que, no início, em Macondo, não se conhece a morte, nem a velhice. Não há fome, nem pobreza. A relação entre o homem e a natureza é harmônica. Por isso, para Selma Calasans Rodrigues (2007), o romance apresenta "um conteúdo utópico insofismável", cujo tema volta-se exatamente para a recuperação das origens, com a firme utopia de que essa recuperação seria um meio de ajudar numa revolução social, ou de superar uma situação de exploração dos povos latino-americanos. Nada mais exemplar do que o começo do romance, descrevendo a utopia de um novo mundo, uma terra sem males, sem governo nem Igreja.

Como lembram Ronan Simioni e Vera Elisabeth Prola Farias (2009, p.160), em poucos meses, Macondo se torna uma aldeia laboriosa e organizada, com suas casas de taquara e chão batido, móveis de madeira construídos pelos próprios donos e coordenada pelo empreendedorismo igualitário de José Arcadio Buendía. Cria-se, então, a visão paradisíaca, a redenção utópica visada pelos sujeitos diasporicamente deslocados ${ }^{15}$. Nesse espaço, a primeira geração da família Buendía, José Arcadio, Aureliano e, posteriormente, Amaranta e Rebeca, essa última sendo filha adotiva do casal, cresce em meio a uma comunidade tranquila e sem divisões sociais.

\footnotetext{
${ }^{15}$ Ainda segundo Simioni e Farias, a significação que envolve o termo diáspora surge, primeiramente, para denominar o fluxo migratório percorrido pelo povo judeu em sua fuga da escravidão no Egito. Sob a liderança de Moisés, o povo escolhido parte em busca de liberdade, da almejada terra prometida, deixando para trás todo o sofrimento vivido no cativeiro da grande "Babilônia". Como argumenta Stuart Hall, é essa a ur-origem da narrativa de libertação, esperança e redenção em um novo mundo, nutrida, principalmente, por grupos humanos em deslocamento espacial. Munido da mesma esperança redentora, José Arcádio Buendía reuniu outros jovens casais, que desmontaram suas moradas e partiram em busca da terra que ninguém prometeu, longe da perturbação provocada pelo espectro do morto. In: SIMIONI, Ronan; FARIAS, Vera Elisabeth Prola. Cem anos de mitos, imperialismos e solidão: Macondo e a (des)construção identitária latino-americana. In: Disc. Scientia, Santa Maria, v.10, n.1, p.147-174, 2009. Série: Artes, Letras e Comunicação, p. 159
} 
Dessa forma, percebemos, no início do romance, a clara projeção da utopia, a crença num mundo perfeito, marcado pela possibilidade da redenção. Essa temática, discutida sobremaneira pelos intelectuais do boom, na década de 1960, parece ter sido marca indelével do período em que a obra foi escrita. A possibilidade de um amanhã de rupturas, com a euforia e a projeção da construção de um mundo mais justo, tornou-se um tema quase obsessivo para os literatos do período. A defesa marcadamente aberta de uma sociedade sem governo e sem distinções sociais, livre de um passado opressor, marca o início da narrativa de García Márquez e parece dialogar diretamente com os debates travados pelos intelectuais do continente na década referida ${ }^{16}$.

\section{A solidão do poder: Macondo à espera de um redentor}

Após certo tempo de existência pueril e inocente, o governo central de uma cidade não mencionada enviou representantes políticos e militares para Macondo, com a intenção de controlar a pequena comunidade. Esse pecado original provocou uma série de guerras civis que, como afirma Lucena (2008, p.74), em Cien años de soledad são parte significativa do enredo, principalmente porque estão relacionadas a uma importante personagem do romance: o coronel Aureliano Buendía.

Como lembram Simioni e Farias (2009, p.161), Aureliano não conseguia entender por qual motivo seu futuro sogro, e recém autoafirmado delegado de Macondo, Apolinar Moscote, promovera a chegada de oito soldados armados para vigiar as eleições no povoado, até então, sem aspirações políticas. A fraude no primeiro pleito eleitoral realizado no local, privilegiando conservadores em detrimento dos liberais,

\footnotetext{
${ }^{16}$ De uma forma geral, os escritores hispano-americanos da década de 1960, em especial o círculo ligado ao boom, retrataram uma América Latina mágica e colorida, ao mesmo tempo engajada num futuro promissor diante da possibilidade da revolução socialista. Nesse período, esses escritores escreveram uma grande quantidade de textos que pensam a América Latina e o papel do escritor latino-americano diante das transformações geradas a partir da Revolução Cubana. A revolução, desde o início, possibilitou a intensa politização de muitos intelectuais latino-americanos, ao colocar na pauta dos assuntos políticos do continente um intenso debate sobre revolução e socialismo. Esse debate atravessou a década do boom e possibilitou a formação de um espaço comum - revistas, jornais, conselhos editoriais, editoras, reuniões, encontros, conferências, correspondências - de intervenção intelectual para os escritores latino-americanos. Para melhor compreensão do tema, ver: VIEIRA, Felipe de Paula Góis. Entre literatura e política: a função social do escritor latino-americano na década de 1960. In: Anais do XXVI Simpósio Nacional de História - ANPUH, São Paulo, julho 2011. Disponível em:

$<$ http://www.snh2011.anpuh.org/resources/anais/14/1312574742_ARQUIVO_EntreLiteraturaePoliticaANPUH\%28Final\%29.pdf $>$. Acesso em 15/03/2012.
} 
veio a desencadear uma série de acontecimentos que operaram o surgimento de heróis revolucionários, contrários à repressão imposta pelos vencedores forjados.

A partir do ingresso do coronel Aureliano na guerra, os governos liberal e conservador se revezavam no poder em Macondo. O povo quase não notava a diferença entre os lados, pois o que realmente aparecia era a violência empregada contra o adversário, comum a ambas as facções. A corrupção e a fraude caracterizavam os dois governos. A partir desse momento, a história de Macondo foi invadida por lideranças que usavam o poder em benefício próprio e não distinguiam o privado do público na vida política do povoado. Em especial, líderes políticos em guerras particulares, não preocupados com o bem comum.

Como salienta Cunha (2007, p.60), a violência incorporou-se a vida cotidiana, banalizou-se e operou transformações nos homens, determinando o comportamento dos seus personagens. O caso mais exemplar é, talvez, o de Arcádio, filho de José Arcadio (irmão de Aureliano) e Pilar Ternera. Quando se iniciou a guerra civil, Arcádio foi designado por seu tio, o coronel Aureliano Buendía, como chefe civil e militar do povoado. Ao tomar o poder, transformou-se em um brutal ditador, que morreu fuzilado quando os conservadores retomaram o governo.

\footnotetext{
Desde el primer día de su mandato Arcadio reveló su afición por los bandos. Leyó hasta cuatro diários para ordenar y disponer cuanto le pasaba por la cabeza. Implantó el servicio militar obligatorio desde los dieciocho años [...] e impuso a los hombres mayores de edad la obligación de usar un brazal rojo. Recluyó al padre Nicanor en la casa cural, bajo amenaza de fusilamiento, y le prohibió decir misa y tocar las campanas como no fuera para celebrar las victorias liberales. Para que nadie pusiera en duda la severidad de sus propósitos, mandó que un pelotón de fusilamiento se entrenara en la plaza pública disparando contra un espantapájaros. Al principio nadie lo tomo en serio. [...] Pero una noche, al entrar Arcadio en la tienda de Catarino, el trompetista de la banda lo saludó con un toque de fanfarria que provocó las risas de la clientela, y Arcadio lo hizo fusilar por irrespeto a la autoridad. A quienes protestaron los puso a pan y agua con los tobillos en un cepo que instalo en cuarto de la escuela. [...] Arcadio siguió apretando los torniquetes de un rigor innecesario, hasta convertirse en el más cruel de los gobernantes que hubo nunca en Macondo. (MÁRQUEZ, 2011, p.131)
}

Arcádio se tornou o exemplo perfeito da corrupção pelo poder, da sede de vingança e do governo arbitrário em Macondo. Seus desmandos acabaram apenas quando Úrsula interveio e lhe aplicou uma surra homérica, diante da possibilidade do fuzilamento da família do Dr. Apolinar Moscote. Após o episódio, o filho bastardo da 
família Buendía acabou fuzilado a mando do governo conservador, também arbitrário e violento.

Mais interessante ainda é pensar que, em meio a essas turbulências, dentro do romance, opera-se a construção do mito do coronel Aureliano Buendía. Aquele que inicialmente havia comandado "veintiún hombres menores de treinta años", armados apenas com "cuchillos de mesa y hierros afilados" (MÁRQUEZ, 2011, p.128), acaba se tornando o herói revolucionário mais temido e respeitado da região.

Após os episódios que desencadearam a sublevação contra o governo conservador em Macondo, a transformação de Aureliano em herói revolucionário obedece à lógica do chamado.

\begin{abstract}
Los rebeldes [...] apenas tuvieron tiempo de despedirse de sus esposas, a quienes abandonaron a sus próprios recursos. Se fueron al amanecer, aclamados por la población liberada del terror [...]. Antes de irse, Aureliano saco a don Apolinar Moscote de un armario. "Usted se queda tranqüilo, suegro" le dijo. "El nuevo gobierno garantiza, bajo palabra de honor, su seguridad personal y la de su família". Don Apolinar Moscote tuvo dificultades para identificar aquel conspirador de botas altas y fusil terciado a la espalda con quien había jugado dominó hasta las nueve de la noche.

- Esto es un disparate, Aurelito - exclamó.

- Ningún disparate - dijo Aureliano -. Es la guerra. Y no me vuelva a decir Aurelito, que ya soy el coronel Aureliano Buendía. (MÁRQUEZ, 2011, p.128)
\end{abstract}

O jovem ourives, construtor de peixinhos dourados, outrora inocente, recluso e pouco afeito aos trâmites da política, converteu-se de forma impressionante no coronel Aureliano Buendía. Diante das contingências históricas, não há meio termo ou contemporização: a decisão é imediata. Como lembra o historiador Mexicano Henrique Krauze (2011), em artigo publicado pelo El País, o culto ao caudilho e ao mito revolucionário tem dominado a história da América Latina. Nesse sentido, torna-se interessante pensar que a transformação de Aureliano em comandante revolucionário obedece ao mito daquilo que Krauze chama "el hombre fuerte", "el héroe providencial" (2011, p. 3).

A partir desse momento, a autoridade e o poder, assim como a capacidade de driblar a morte, seriam características da personalidade marcante do quase herói de Cien años de soledad. Na descrição de Aureliano Buendía, se encontra uma das passagens mais famosas do romance:

El coronel Aureliano Buendía promovió treinta y dos levantamientos armados y los perdió todos. Tuvo diecisiete hijos varones de diecisiete

Revista Eletrônica da ANPHLAC, n.12, p. 254-279, jan./jun. 2012. http://revista.anphlac.org.br/index.php/revista 
mujeres distintas, que fueron exterminados uno tras outro en una sola noche, antes de que el mayor cumpliera treinta y cinco años. Escapó a catorce atentados, a setenta y tres emboscadas y a un pelotón de fusilamiento. Sobrevivió a una carga de estricnina en el café que habría bastado para matar a un caballo. Rechazó la Orden del Mérito que le ortogó el presidente de la república. Llegó a ser comandante general de las fuerzas revolucionarias, con jurisdicción y mando de una frontera a la outra, y el hombre más temido por el gobierno, pero nunca permitió que le tomaran una fotografia. Declinó la pensión vitalícia que le oferecieron después de la guerra y vivió hasta la vejez de los pescaditos de oro que fabricaba em su taller de Macondo. Aunque peleó siempre al frente de sus hombres, la única herida que recibió se la produjo él mismo después de firmar la capitulación de Neerlandia que puso término a casi veinte años de guerras civiles. (MÁRQUEZ, 2011, p.129)

Ainda na perspectiva de Krauze, na América Latina, a sacralização da História na figura de um herói foi responsável pela produção da figura política "de los redentores" (KRAUZE, 2007, p.3). Nesse sentido, para restaurar o equilíbrio e a pureza, perdidos com os desmandos do poder, Macondo possuía, agora, uma espécie de herói caudilho sem os louros da vitória. Apesar da construção do personagem contemplar a derrota como característica principal, é importante que se frise que a liderança derrotada em nenhum momento sucumbe às ingerências do destino. Sua postura permanece intacta, seu poder e autoridade visíveis. A derrota acentua ainda mais a postura do herói, que passa também a cumprir o papel do mártir.

En mayo terminó la guerra. Dos semanas antes de que el gobierno hiciera el anuncio oficial, en una proclama altisonante que prometía un despiadado castigo para los promotores de la rebelión, el coronel Aureliano Buendía cayó prisionero [...] El coronel [...] había sido condenado a muerte, y la sentencia sería ejecutada en Macondo, para escarmiento de la población.

La tropa pugnaba por someter a culatazos a la muchedumbre desbordada. Úrsula y Amaranta corrieron hasta la esquina, abriéndose paso a empellones, y entonces lo vieron. Parecía un pordiosero. Tenía la ropa desgarrada, el cabello y la barba enmarañados, y estaba descalzo. Caminaba sin sentir el povo abrasante, con las manos amarradas a la espalda con una soga que sostenía en la cabeza de su montura um oficial de a caballo. (MÁRQUEZ, 2011, p.150-151)

Após a humilhação pública, Úrsula teve a oportunidade de visitar o filho no cárcere. Mesmo padecendo com o tratamento dispensado pelas tropas conservadoras, $\mathrm{o}$ coronel Aureliano Buendía conservava a impavidez e a postura heroica inalteradas.

Encontró al coronel Aureliano Buendía en el cuarto del cepo, tendido en un catre y con los brazos abiertos [...] Desde el momento en que entró al cuarto, Úrsula se sintió cohibida por la madurez de su hijo, por su aura de domínio, por el resplandor de autoridad que irradiaba su piel. (MÁRQUEZ, 2011, p.153)

Revista Eletrônica da ANPHLAC, n.12, p. 254-279, jan./jun. 2012.

http://revista.anphlac.org.br/index.php/revista 
Diante da morte, o coronel não esmoreceu. Pelo contrário, manteve acesa a figura quase incorruptível do mártir, do herói redentor. "No sintió miedo, ni nostalgia, sino una rabia intestinal ante la idea de que aquella muerte artificiosa no le permitiria conocer el final de tantas cosas que dejaba sin terminar" (MÁRQUEZ, 2011, p.156).

E, apesar da condenação, a agitação popular diante da execução do coronel promoveu o adiamento da sentença.

\begin{abstract}
La rebeldia del pueblo hizo pensar a los militares que el fusilamiento del coronel Aureliano Buendía tendría graves consecuencias políticas no sólo en Macondo sino en todo el ámbito de la ciénaga, así que consultaron a las autoridades de la capital provincial. La noche del sábado, mientras esperaban la respuesta, el capitán Roque Carnicero fue com otros oficiales a la tienda de Catarino. Sólo una mujer, casi presionada con amenazas, se atrevió a llevarlo al cuarto. "No se quieren acostar con un que saben que se va a morir", le confesó ella. "Nadie sabe cómo será, pero todo mundo anda diciendo que el oficial que fusile al coronel Aureliano Buendía, y todos los soldados del pelotón, uno por uno, serán asesinados sin remédio, tarde o temprano, así se escondan en el fin del mundo". (MÁRQUEZ, 2011, p.157)
\end{abstract}

Gabriel Souza Sordi (2009, p.26) ressalta como a presença do "grande homem", como "dirigente imprescindível", permeou a história do continente latino-americano durante o século $\mathrm{XX}$, em especial, no início do referido século, nas análises historiográficas e biografias de José de San Martín e Simón Bolívar. Segundo o pesquisador, a necessidade da luta armada, no caso das independências latinoamericanas, propiciou o surgimento de um tipo militarista de herói, aglutinador dos anseios de libertação e responsável pela promoção da mesma. Dentro da construção do culto a esses heróis, estaria um padrão de comportamento possível de ser observado em suas narrativas canônicas: a potencialidade de sua condução revolucionária, a vontade expressa de doar a vida pela soberania política, a encarnação da nacionalidade e a exemplaridade cívica.

Apesar de não seguir a risca o exemplo do herói caudilho, construído pela historiografia do início do século XX, o personagem de García Márquez possui uma ligação direta com esse tipo de narrativa. Sua postura inquebrantável, sua aura de autoridade e sua ligação direta com o povo mostram a aposta numa redenção comandada pelo herói ${ }^{17}$.

\footnotetext{
${ }^{17}$ Selma Calasans Rodrigues enxerga na construção de Aureliano Buendía o oposto do herói. Segundo a autora, "no sexto capítulo do livro já sabemos, pela antecipação da narrativa, que as guerras são uma total derrisão, que não há herói nem qualquer heroicidade possível, e que o episódio do pelotão de fuzilamento acaba numa total farsa”. In: RODRIGUES, Selma Calasans. Op. Cit, 1993. p. 82. Nesse ponto, a análise
} 
Com a ordem de execução confirmada pela capital da província, alguns dias depois, o coronel Aureliano Buendía estava diante do pelotão de fuzilamento. Não perdendo por um instante a raiva intestinal e a coragem que lhe eram típicas, murmurava: "Tanto joderse para que lo maten a uno seis maricas sin poder hacer nada" (MÁRQUEZ, 2011, p.157). No entanto, apesar da situação adversa, como anuncia o primeiro parágrafo do romance, o destino haveria de interceder pela figura do bravo coronel. O algoz, capitão Roque Carnicero, militar responsável pela execução, diante da intervenção de José Arcádio, suspendeu fogo e passou ao lado do movimento revolucionário. Começava, assim, outra guerra, uma das muitas perdidas pelo coronel Aureliano Buendía.

Segundo Rodrigues (1993, p.84), a partir desse momento, sua figura tornava-se cada vez mais mítica, já que as notícias sobre o coronel eram contraditórias e grandiloquentes: ora manchetes jubilosas (para o governo) anunciavam-no morto; ora o anunciavam chefiando outra rebelião nas planícies do sul; ora desistindo de lutar no país para lançar-se ao lado do federalismo triunfante em outras repúblicas do Caribe, pretendendo varrer os conservadores do Alasca até a Patagônia. Assim, criou-se a lenda da ubiquidade do personagem.

deste artigo caminha em posição oposta àquela defendida pela autora. Apesar do coronel Aureliano Buendía não seguir a descrição esperada de um herói, e sua trajetória caminhar invariavelmente rumo ao fracasso, adotamos, aqui, postura analítica semelhante àquela defendida por Fabiana de Souza Fredrigo, ao analisar o romance El general en su laberinto (1989). Segundo Fredrigo, análises mais tradicionais tendem e enfatizar o sentido dessacralizador da narrativa de García Márquez, ao abordar os últimos dias de vida de Bolívar. Para maior parte dos autores que se debruçam sobre o livro, o que chama a atenção é a ênfase num Bolívar derrotado, nada heroico, diferente de certo discurso historiográfico de início do século, que lhe atribui uma aura sacra e exemplar. A hipótese levantada por Fredrigo é de que a narrativa de El general en su laberinto não pode ser entendida sem a relação que se estabelece com o epistolário bolivariano. Para a autora, o texto literário de García Márquez, além de usar as cartas de Bolívar para construir seu personagem e a cena romanesca, reforça o culto ao general libertador. As descrições do personagem no livro contemplam um homem abatido, que caminhava para a morte. Entretanto, um grau de surpresa é atribuído ao sempre presente adendo do homem fisicamente decadente: apesar da doença, Simón Bolívar tinha movimentos decididos e alma capaz de restaurar suas forças, mesmo após uma noite inteira de delírio. "Assim, a escolha de Gabriel García Márquez é a de apresentar um general perdido, decadente, sem apoio, ressentido, doente; mas um general que conservava no espírito o sinal da liderança forte e vigorosa" In: FREDRIGO, Fabiana de Souza. A correspondência de Simón Bolívar e sua presença na literatura: uma análise de $O$ General em seu labirinto de Gabriel García Márquez. In: História, São Paulo, v.28, n.1, pp.715-756, 2009. p. 728 . Acreditamos que a opção por apresentar o coronel Aureliano Buendía e seus projetos revolucionários como derrotados não subtrai o seu ar de heroísmo e a crença no líder redentor. Afinal, as descrições de sua personalidade e seus gestos apresentam sempre o sinal da liderança forte e vigorosa, mesmo que ao final ela se mostre infrutífera, como o Bolívar de El general en su laberinto. O tema do caudilho e a solidão do poder ofereceram material para outros personagens e livros de García Márquez: o presidente do conto "Boa viagem, senhor presidente" em Doce cuentos peregrinos (1992) e El otoño del patriarca (1975). Percebe-se, portanto, a obsessão do escritor colombiano com o tema da liderança redentora.

Revista Eletrônica da ANPHLAC, n.12, p. 254-279, jan./jun. 2012. http://revista.anphlac.org.br/index.php/revista 
No entanto, apesar dos trinta e dois levantamentos armados, como lembra Cunha (2007, p.61), o coronel Aureliano Buendía, antes de a guerra terminar, decidiu abandoná-la. A assinatura do armistício se fez a 20 quilômetros de Macondo, dentro de uma barraca remendada de circo.

El coronel Aureliano Buendía llegó en una mula embarrada. Estaba sin afeitar, más atormentado por el dolor de los golondrinos que por el inmenso fracaso de sus sueños, pues había llegado al término de toda esperanza, más allá de la gloria y de la nostalgia de la gloria. (MÁRQUEZ, 2011, p.215)

Desse modo, terminou a guerra civil em Macondo. Como salienta Rodrigues (1993, p.87), do Dom Quixote macondino ficava apenas o nome e a lembrança de muitas outras guerras e atentados, que também se apagariam da memória do povoado, desgastado ao final de cem anos de história. Um soldado trouxe para o Coronel notícias do resultado de sua luta inglória. Um verdadeiro carnaval político foi o saldo de tudo, narrado no estilo enumerativo, hiperbólico, irônico e paródico do autor colombiano. Assim foram as últimas notícias que Aureliano se permitiu ouvir:

\footnotetext{
Que el gobierno conservador, decía, con el apoyo de los liberales, estaba reformando el calendário para que cada presidente estuviera cien años en el poder. Que por fin se había firmado el concordato con la Santa Sede, y que había venido desde Roma un cardeal con una corona de diamantes y un trono de oro macizo, y que los ministros liberales se habían hecho retratar de rodillas en el acto de besarle el anillo. Que la corista principal de una compañía española, de paso por la capital, había sido secuestrada en su camerino por un grupo de enmascarados, y el domingo siguiente había bailado desnuda en la casa de verano del presidente de la república. "No me hables de política", le decía el coronel. "Nuestro asunto es vender pescaditos". (MÁRQUEZ, 2011, p.241)
}

Fatigado por uma luta sem sentido e completamente desiludido, o coronel se afastou da política e se refugiou num quarto dos fundos de sua casa, onde sozinho distraia-se fazendo e desfazendo peixinhos. Assim, dentro do romance de García Márquez, se Macondo caminhava em direção à destruição era porque o projeto do coronel se desvaneceu diante dos jogos de poder e das disputas políticas, temática semelhante ao que anos mais tarde viria compor o enredo de El general en su laberinto (1989).

\section{Macondo nas garras do imperialismo}

Com o fim das guerras civis, Macondo viveu outra página de sua história: a luta contra o imperialismo e a exploração do capital estrangeiro. Na perspectiva de 
Rodrigues (1993, p.87), essa era a última "praga", paralela e homóloga às guerras, a invadir a realidade do povoado. $\mathrm{Na}$ visão da autora, a invasão imperialista da Companhia Bananeira era, sem dúvida, uma sátira a United Fruit, exportadora norteamericana de frutas tropicais, que exerceu um poder indiscriminado na América hispânica.

A penetração americana em Macondo é rápida e, segundo Rodrigues (1993, p.88), subreptícia. É o coronel Aureliano Buendía quem sintetiza: "Miren la vaina que nos hemos buscado [...] - no más por invitar un gringo a comer guineo" (MÁRQUEZ, 2011, p.276). O exame meticuloso feito por Mr. Hebert na banana, medindo unidade, peso, intensidade da luz, caricatura muito bem a atitude do povo progressista e tecnológico que fará da banana um objeto de exploração colonialista. Também a enumeração dos técnicos que, da noite para o dia, penetraram em Macondo completa o quadro ideológico.

Essa "peste" (a Companhia Bananeira), que, de acordo com os habitantes, lembrava as guerras do Coronel Aureliano, era responsável, segundo Figueroa (1998, p.118), por introduzir a injustiça social no tempo histórico de Macondo. A presença da Companhia acabava por quebrar o mundo das realidades essenciais e modificar o aspecto físico do povoado: os visitantes indesejados "modifican el régimen de la lluvias, apresuran el ciclo de las cosechas y quitaron el río de donde estuvo siempre" (MÁRQUEZ, 2011, p.197).

Os americanos se instalaram num acampamento à parte, em casas cercadas de conforto e separadas dos demais por uma rede metálica, comparada, segundo Rodrigues (1993, p.88), em linguagem cotidiana, a um "gallinero electrificado que en los frescos meses del verano amanecía negro de golondrinas achicharradas” (MÁRQUEZ, 2011, p.274). Esse detalhe do acampamento marcava o desejo de isolamento dos invasores em relação à população.

A primitiva fascinação pelo "progresso", pela comunicação com os povos de fora e seus aparelhos mágicos, polarizada nos anseios de José Arcádio Buendía, se convertia agora em derrisão e em nostalgia de um paraíso original perdido.

Como lembra Krauze (2011, p.398), um elemento central na consciência política de García Márquez é seu anti-imperialismo. Isso é manifesto (e originalmente formado) como fatos genuínos e elaborações literárias ao redor do assunto da United Fruit 
Company. Em Cien años de soledad, Aracataca não era apenas uma cidade que girava ao redor de uma empresa (com suas plantações, estradas de ferro, sala de telégrafo, portos, hospitais e frotas), mas também o cenário da "maldição bíblica" do imperialismo ianque, uma força histórica de grande alcance, cuja "inspiração messiânica" mexia com as esperanças de milhares, apenas para sujar as águas do paraíso original, perturbar a paz e explorar seu povo.

Assim, em pouco tempo, os "pobres diabos" (termo empregado pelo Coronel Aureliano Buendía) dos conservadores, então governantes de Macondo, se converteram em prefeitos sem iniciativa, juízes decorativos, que se tornaram servis diante da presença dos estrangeiros. Num intervalo de tempo ainda menor, as autoridades locais foram substituídas por forasteiros autoritários e sicários armados de facões que mr. Brown levava para viver nas comodidades do "gallinero electrificado".

Por fim, a invasão da Companhia Bananeira terminou de forma trágica e sangrenta: ela foi responsável pela matança de três mil trabalhadores em Macondo. Como lembra Forgiarini (2009, p.69), os operários em greve rebelaram-se contra as condições de trabalho oferecidas pela companhia e foram duramente reprimidos. Três mil pessoas se reuniram na praça da estação ferroviária. Eram trabalhadores, suas mulheres e crianças. Eles esperaram a chegada da autoridade civil e militar da província, que viria decidir o conflito entre o povoado e a empresa, a fim de evitar uma guerra desigual. O exército ficara responsável por manter a ordem pública. Nesse ponto, uma tragédia tornava-se cada vez mais eminente. Em meio ao turbilhão de pessoas, o tenente subiu ao teto para ler ao megafone o Decreto número quatro do Clube Civil e Militar da província, que "declaraba a los huelguistas cuadrilla de malchechores y facultaba al ejército para matarlos a bala" (MÁRQUEZ, 2011, p.364).

José Arcadio Segundo (na verdade, Aureliano Segundo) era um dos três mil trabalhadores que enfrentou, encurralado em frente à estação ferroviária de Macondo, as metralhadoras disparadas sem trégua. Juntamente com outros trabalhadores e familiares (mulheres, crianças), foi colocado dentro de enorme trem, com quase duzentos vagões e três locomotivas, normalmente usado para carregar bananas, mas que foi empregado para carregar os corpos dos três mil homens que haviam protestado na praça. Havendo milagrosamente sobrevivido ao fuzilamento, José Arcadio Segundo tornou-se a única testemunha do massacre.

Revista Eletrônica da ANPHLAC, n.12, p. 254-279, jan./jun. 2012. http://revista.anphlac.org.br/index.php/revista 
Dias depois, o governo decretou que nada havia acontecido em Macondo, e que a população, feliz, havia voltado para casa. Essa versão dos acontecimentos, imposta pelo poder, como salienta Rodrigues (1993, p.93), é a que predominaria na consciência da população desmemoriada. Apesar dos esforços de José Arcádio Segundo em relatar as três mil mortes, ninguém acreditou em sua versão da história. "En Macondo no ha pasado nada, ni está pasando ni pasará nunca. Este es un pueblo feliz" (MÁRQUEZ, 2011, p.370).

Após o massacre ser omitido pelas autoridades governamentais e distorcido pelos meios de comunicação, a Companhia Bananeira suspendeu suas atividades e foi embora de Macondo, deixando para trás uma aldeia que entrou em gradual decadência, motivada também pela intermitente chuva que no universo fictício de Gabriel García Márquez durou 4 anos, 11 meses e 2 dias.

\section{Considerações finais}

Diante do recorte proposto para análise da obra, o que percebemos é que das páginas de Cien años de soledad vislumbra-se a perspectiva de uma América Latina marcada por lutas internas pelo poder, pela corrupção, pela violência gerada por obscuras guerras civis entre liberais e conservadores, pela exploração descontrolada do capital estrangeiro através da "febre da banana", pela greve dos trabalhadores e a repressão do exército. Mais do que isso, vislumbra-se uma América possivelmente redimida pela figura do herói redentor, na figura do caudilho, e da revolução.

Para Selma Calasans Rodrigues (1993, p.10), não podemos esquecer que a geração do boom foi, por certo, a geração das utopias, das grandes construções, crenças e questionamentos. Segundo Figueroa (1998, p.119-120), apesar do final apocalíptico do romance, em Cien años de soledad não há uma condenação total. A obra, como os grandes textos, prolonga-se em seus leitores e em outros textos de seu autor. É preciso lê-la prolongada e transformada no discurso de aceitação do Prêmio Nobel de Literatura, quando García Márquez, depois de mostrar o tamanho da nossa solidão histórica e depois de explicitar as implicações profundas da busca do ser latinoamericano, termina cantando a vida e a esperança, anunciando, então, a boa nova que estava ausente na novela. E, ao final desse canto, anuncia a segunda oportunidade, a possibilidade iluminada de outra utopia:

Revista Eletrônica da ANPHLAC, n.12, p. 254-279, jan./jun. 2012. http://revista.anphlac.org.br/index.php/revista 
una nueva y aterradora utopía de la vida, donde nadie pueda decidir por otros hasta la forma de morir, y donde de veras sea cierto el amor y sea posible la felicidad y donde las estirpes condenadas a Cien años de soledad tengan por fin y para siempre una segunda oportunidad sobre la tierra. (MÁRQUEZ, 1982)

Essas representações de Macondo, lidas e interpretadas como metáforas do contexto histórico latino-americano, solidificaram-se como explicações plausíveis e possíveis da realidade do continente. O sucesso do romance, como afirmamos no início do artigo, habituou leitores do mundo todo a perceber a América como espaço da utopia, da revolução, do intelectual de esquerda, das lutas pelo poder etc. Esse padrão narrativo solidificou-se como cânone e foi, de forma mais sistemática, contestado a partir dos anos 1990, momento em que praticamente desaparece da cena pública, em razão das mudanças de paradigmas intelectuais e das transformações conjunturais, a figura do intelectual engajado. Para Helenice Rodrigues da Silva (SILVA, 2003), o enfraquecimento das ideologias do progresso e a ascensão dos valores individualistas explicam, em grande parte, o final de um modelo de intelectual que buscava, através de seus atos públicos, aliar moral e política.

\section{Fontes primárias}

MÁRQUEZ, Gabriel García. Cien años de soledad. Barcelona: Contemporanéa, 2011. . Cem anos de solidão. Rio de Janeiro: Record, 2009.

. Discurso de Gabriel García Márquez en su homenaje en Cartagena durante la jornada inaugural del IV Internacional de la Lengua Española". Cartagena de Indias, Colombia, 27 de marzo de 2007. Disponível em: $<$ http://www.oei.es/garciamarquez.pdf $>$. Acesso em 01/08/2011.

. La soledad de America latina. Discurso de aceitação do Prêmio Nobel de Literatura de 1982. Disponível em http://nobelprize.org/. Acesso em 26/05/2009.

. La penumbra del escritor de cine. In: El Espectador, [é um periódico? Se sim, completar com o local de publicação]17 de novembro de 1982.

JIMÉNEZ, Rafael. Apud: Aracataca rechaza en referéndum añadir a su nombre el de Macondo, en alusión al pueblo de Cien años de soledad. In. Cultura/La Vanguardia.com (online), Bogotá, publicado em: 26/06/2006. Disponível em: http://www.lavanguardia. com/cultura/20060626/51274735722/aracataca-rechaza-en-referendum-anadir-a-su nombre-el-de-macondo-en-alusion-al-pueblo-de-cien-anos.html. Acesso em 01/08/2011. 


\section{Referências Bibliográficas}

ARANGO, Manuel Antonio L. La temática y el aspecto social en Cien años de soledad de Gabriel García Márquez. In: Cuadernos Americanos, Cidade do México, v.38, n.224, p. 204-216, 1979.

BALDUSSI, Rosa Fortuna Boldori de. Cien años de soledad y la novela mundo Latinoamericana. In: Universidad Nacional del Litoral, Santa Fé, Argentina, n.79, p.21106,1969.

BENEDETTI, Mario. Temas y problemas. IN: MORENO, César Fernández (Org.). América latina en su literatura. México: Siglo Veintiuno, 2000. p. 354-371

BRUNER, José Joaquín. Cartografias de la modernidad. Santiago de Chile: Dolmen Ediciones, 1994. p. 151-190.

COSTA, Adriane A. Vidal. Intelectuais, política e literatura na América Latina: o debate sobre revolução e socialismo em Cortázar, García Márquez e Vargas Llosa (1958-2005). Belo Horizonte, 2009. Tese (Doutorado em História) - FAFICH/UFMG.

CUNHA, Karla Pereira. Gabriel García Márquez e Octávio Paz: a questão da identidade ibero-americana em Cien años de soledad e El laberinto de la soledad. Juiz de Fora, 2007. Dissertação (Mestrado em História) - UFJF.

DONOSO, José. História personal del “boom”. Barcelona: Seix Barral, 1983.

FIGUEROA, Cristo. Cien años de soledad: reescritura bíblica y posibilidades del texto sagrado. In: XX Congreso Nacional de Literatura, Lingüística y Semiótica: Cien años de soledad, treinta años después. Santafé de Bogotá, 1998.

FORGIARINI, Nadia Terezinha Arzivenko. Intertextos míticos em Cem anos de solidão. Frederico Westephalen, 2009. Dissertação (Mestrado em Letras) URI/Universidade Regional Integrada do Alto Uruguai e das Missões.

FREDRIGO, Fabiana de Souza. A correspondência de Simón Bolívar e sua presença na literatura: uma análise de $O$ General em seu labirinto de Gabriel García Márquez. In: História, São Paulo, v.28, n.1, p.715-756, 2009. 
FUENTES, Carlos. Eu e os outros: ensaios escolhidos. Rio de Janeiro: Rocco, 1989.

GILMAN, Claudia. Entre la pluma y el fusil: debates y dilemas del escritor revolucionario en América Latina. Buenos Aires: Siglo XXI, 2003.

HALL, Stuart. Da diáspora: identidades e mediações culturais. Belo Horizonte: Editora UFMG, 2003.

LLOSA, Mario Vargas. La novela en América Latina: diálogo. Lima: C. M. Batres, Universidad Nacional de Ingenieria, 1967.

LUCENA, Karina de Castilhos. Macondo: além da terra firme (um estudo sobre a cidade imaginária). Caxias do Sul, 2008. Dissertação (Mestrado em Letras) - UCS.

MEDINA, Alberto Anes. La paráfrasis de los mitos en Cien años de soledad". In: Revista de la Universidad de Zulia, Maracaibo, Venezuela, n. 54, p. 72-87, 1974.

MÁRQUEZ, Gabriel García. Cem anos de solidão. Rio de Janeiro: Record, 2009.

MARTIN, Gerald. Gabriel García Márquez: uma vida. Rio de Janeiro: Ediouro, 2010.

NEPOMUCENO, Eric. "Gabriel García Márquez: duas anotações para um perfil” IN: GARCÍA MÁRQUEZ, Gabriel. Cem anos de solidão. Rio de Janeiro: Record, 2009. p. 15-38.

PESAVENTO, Sandra Jatahy. História \& literatura: uma velha-nova história. Nuevo Mundo Mundos Nuevos, Debates, Paris, s/n, 28 de janeiro de 2006.

RODRIGUES, Selma Calasans. Macondoamérica: a paródia em Gabriel García Márquez. Goiânia: Editora UFG, 2001.

SORDI, Gabriel Souza. El protector y su pueblo libre: a representação do caudilho José Artigas no centenário de sua morte (1950). Campinas, 2009. Dissertação (Mestrado em História) - IFCH/UNICAMP.

STRATHERN, Paul. García Márquez em 90 minutos. Rio de Janeiro: Jorge Zahar Ed., 2009. 